July 2009

\title{
Foundations in Neurological Surgery
}

Ashwini Sharan MD

Thomas Jefferson University

Follow this and additional works at: https://jdc.jefferson.edu/jhnj

\section{Let us know how access to this document benefits you}

\section{Recommended Citation}

Sharan MD, Ashwini (2009) "Foundations in Neurological Surgery," JHN Journal: Vol. 4 : Iss. 3 , Article 2. DOI: https://doi.org/10.29046/JHNJ.004.3.002

Available at: https://jdc.jefferson.edu/jhnj/vol4/iss3/2

This Article is brought to you for free and open access by the Jefferson Digital Commons. The Jefferson Digital Commons is a service of Thomas Jefferson University's Center for Teaching and Learning (CTL). The Commons is a showcase for Jefferson books and journals, peer-reviewed scholarly publications, unique historical collections from the University archives, and teaching tools. The Jefferson Digital Commons allows researchers and interested readers anywhere in the world to learn about and keep up to date with Jefferson scholarship. This article has been accepted for inclusion in JHN Journal by an authorized administrator of the Jefferson Digital Commons. For more information, please contact: JeffersonDigitalCommons@jefferson.edu. 


\section{Foundations in Neurological Surgery}

\section{Ashwini D. Sharan, MD}

Department of Neurological Surgery, Thomas Jefferson University, Philadelphia, PA

Continuously searching for ways to improve resident education, Dr. Ashwini Sharan has begun a series of classes for residents. Each class is a one-day session focused on a specific set of techniques that the resident will need competency in. Using a traditional class format means that each resident is not only drilled on specific skills, but also gets to learn from his fellow students - and future colleagues - by observing them perform the same tasks. The Congress of Neurological Surgeons conference has similar workshops where practicing neurosurgeons can get familiarity with new tools. These classes are intended to ensure that residents enter the OR with a solid foundation of basic skills.

The first class was conducted with support from Stryker, a medical technology firm which is interested in staging similar courses at universities around the country.

This pilot class focused on Emergency Neurological Surgery. As important as forethought and planning are in surgery, speed is even more so. The resident should strive to develop automatic, accurate decision-making skills in order to conserve precious time. In this class, Dr. Sharan walked the residents through the thought processes that would have to become reflexive.

The residents were presented with a hypothetical patient (see inset), with a medical history and set of exam results. In the oral neurosurgical boards, the examinee receives such a scenario and must present justifiable clinical decisions without hesitation, confusion or ambiguity. In this class, the junior residents listened as Dr. Sharan led them through the reasoning process. First, he reviewed the Glasgow Coma Scale, which rates the patient on eye, verbal and motor responses in order to assess the severity of a coma. He then reviewed the signs, dangers and treatment of increased intracranial pressure.

After another lecture, this one on positioning of the patient, the hands-on sessions began. Dr. Sharan gave a lecture on a topic - power drills, dural closure, or rigid fixation - and the residents practiced with anatomical models or other analogues such as a beef scapula. For the practicum on patient positioning, the demonstration models were senior residents who bore their duties with good humor.

The class is one of a series Dr. Sharan plans to hold. Projected topics are spine surgery and placement of central lines. These courses will be planned in collaboration with medical device companies and will also take advantage of educational resources available at Thomas Jefferson University such as the simulation classrooms.
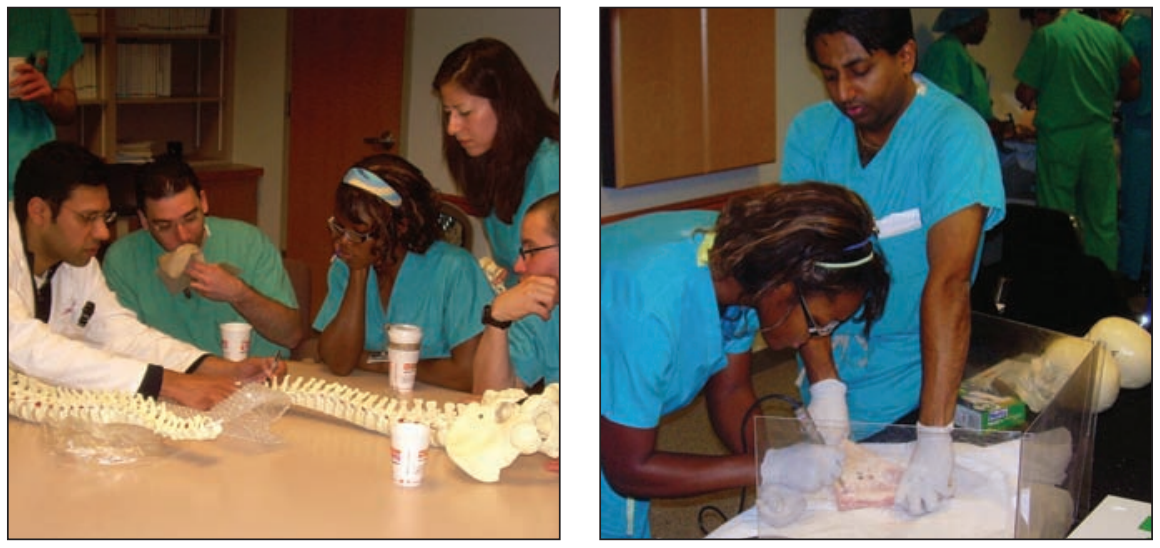

64 year-old female Hx right frontal ICH No residual weakness AA 325, CMD for Afib Sudden onset $30 \mathrm{~min}$.

\begin{tabular}{ll}
\hline Exam & Somnolent \\
& Anisocoria \\
& O x 1 \\
& Dysarthric \\
& FCs left intermittently
\end{tabular}

"One of our interns made it into the OR to make burr holes on Monday (following the Saturday course) - I spoke with the attending and he gave him an A-. Not bad for his first time in the OR. I really think placing a drill into his hand in a lab will have made all the difference."

- Dr. Ashwini Sharan

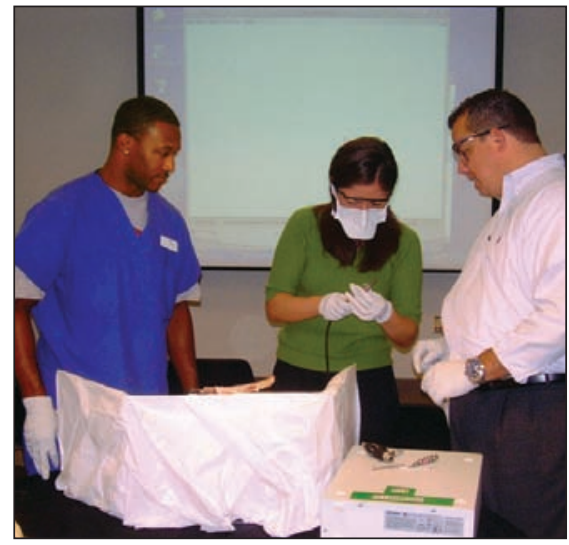




\section{Educational Objectives}

Upon completion of this course, the physician should be able to:

1. Discuss the care of the emergency neurological surgical patient.

2. Determine appropriate body positioning and surgical approaches required for access to multiple lobes of the brain.

3. Describe the appropriate application of current and innovative technologies and instrumentation to treat patients requiring neurological surgical intervention.

4. Identify steps to intervene when complications or comorbidities contribute to complications that arise when treating neurological surgical patients.

\begin{tabular}{ll}
\hline Residency Proficiency Checklist & \\
\hline Resident Shows Proficiency in: & $\begin{array}{l}\text { Cranial fixation - Mayfield } \\
\text { fixation device }\end{array}$ \\
\hline & Creating burr holes \\
\hline & Dural closure \\
\hline Turning the cranial flap \\
\hline $\begin{array}{l}\text { Use of plates and screws for rigid } \\
\text { fixation of the bone flap }\end{array}$ \\
\hline $\begin{array}{l}\text { Use of hydroxyapatite cement and } \\
\text { titanium mesh for cranioplasty }\end{array}$ \\
\hline
\end{tabular}

\section{Agenda: Emergency Neurological Surgery}

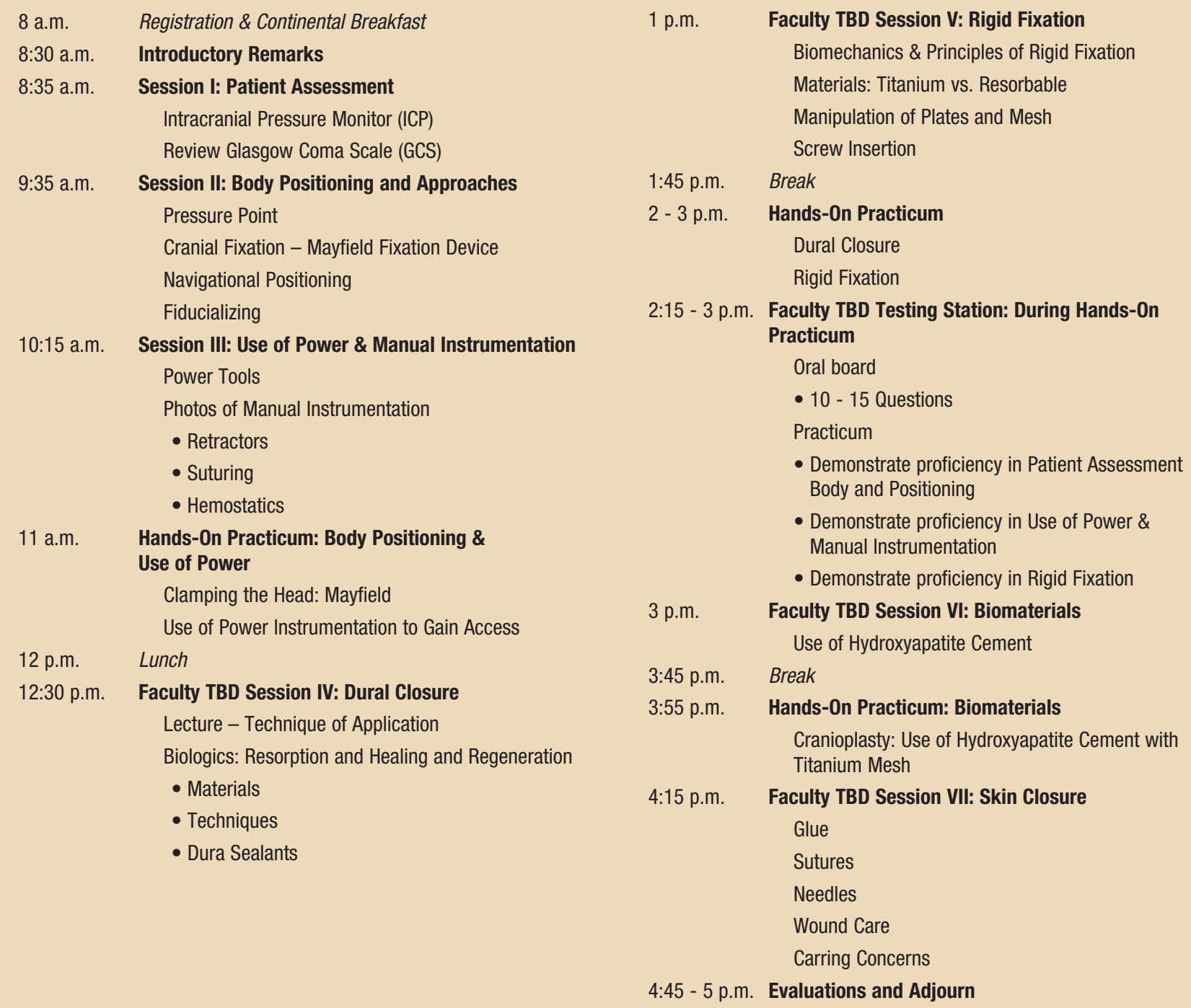

